\title{
Determination of the Critical Period of Phytosanitary Treatment against Cowpea (Vigna unguiculata L. Walp) Pests in Southern Togo
}

\author{
Tounou Agbéko Kodjo1 ${ }^{1}$, Bakouma Batossa Emmanuel1, \\ Nyamador Wolali Seth ${ }^{2}$, Agboka Komi ${ }^{1}$
}

\author{
${ }^{1}$ Laboratoire de Recherche sur les Agroressources et la Santé Environnementale, Ecole Supérieure d'Agronomie, \\ Université de Lomé, 01 BP : 1515 Lomé 1-Togo \\ ${ }^{2}$ Laboratoire d'Entomologie Appliquée, Faculté des Sciences, Université de Lomé, 01 BP 1515 Lomé 1
}

\begin{abstract}
Economically efficient and environmentally friendly technology is essential for sustainable agricultural production. To optimize cowpea production through an economically profitable and environmentally friendly phytosanitary treatment technology, trials were conducted in a station based on Acarius 18 EC at a rate of 1 liter/ha against the main cowpea insect pests. A complete randomized block device with three replications of four objects each with two sub-trials: an early competition (EC) sub-trial and a late competition (LC) sub-trial were adopted. Seed yield and the critical period for phytosanitary treatment have been determined. The best yields were obtained on objects that received the first treatment 28 days after sowing (DAS) (2.13 t/ha on average) for EC and on objects that received the last treatment 42 DAS (2.23 t/ha on average) for LC. Under the conditions of our study, the critical period of phytosanitary treatment against cowpea pests (VITOCO) for optimum yield is then between 28 and 42 DAS.
\end{abstract}

Keywords: Cowpea Pests, Early Competition, Late Competition, Critical Treatment Period

\begin{abstract}
Introduction
Strategies for poverty reduction and food security in Africa must always include agricultural development. They involve the dissemination of technologies to improve crop productivity. Among the most widely grown legumes in Africa, cowpea (Vigna unguiculata L. Walp (Fabales: Fabaceae)) is one of the main legumes produced and consumed in the world and particularly in West Africa (Pasquet and Baudoin, 1997). Its economic importance, its high protein content and its importance in the diet of populations make this legume an important crop in reducing poverty and improving food security (Singh et al., 1990). Its nitrogen requirements are low; its roots have nodules filled with bacteria (Rhizobium) that fix atmospheric nitrogen. According to FAO (2009), the annual world production of cowpea is 3.23 million tonnes out of approximately 12 million hectares and 2.99 million tonnes are produced in sub-Saharan Africa out of 10.92 million hectares with West Africa in first place (2.55 million tonnes per year out of 10.26 million hectares). Cowpea production in Togo is 0.2 tonnes per hectare (FAOSTAT, 2013) compared with a potential yield of 3 tonnes per hectare (Rusoke and Rubaihayo, 1994). This level of
\end{abstract}

production is far from satisfying the ever-increasing demand for cowpeas in the world and particularly in West Africa. Indeed, cowpea yields in Africa are still very low and range from 200 to $700 \mathrm{~kg} / \mathrm{ha}$ compared to 1000 to $1500 \mathrm{~kg} / \mathrm{ha}$ in the United States of America (Dugje et al., 2009). This low yield is due to several constraints: these are mainly diseases, insect pests and weeds. The losses caused by these biotic factors are estimated at nearly US\$300 million per year (NRI, 1991). However, pests and diseases are the major constraint to cowpea production (Atachi and Adeoti, 2004). Thus, the fight against pests and diseases is a major issue in the production of cultivated cowpeas. The success of the harvest depends on the success of this fight. The only suppression method available to producers is the use of synthetic chemicals. This method is effective for pest control but has disadvantages. Chemicals used for treatment can contribute to ecosystem pollution, increased risk to the health of its users and the development of resistance in insect populations (Brown, 1957). This level of production is far from satisfying the ever-increasing demand for cowpeas in the world and particularly in West Africa. Indeed, cowpea yields in Africa are still very low and range

This article is published under the terms of the Creative Commons Attribution License 4.0

Author(s) retain the copyright of this article. Publication rights with Alkhaer Publications.

Published at: http://www.ijsciences.com/pub/issue/2018-09/

DOI: 10.18483/ijSci.1783; Online ISSN: 2305-3925; Print ISSN: 2410-4477 
from 200 to $700 \mathrm{~kg} / \mathrm{ha}$ against 1000 to $1500 \mathrm{~kg} / \mathrm{ha}$ in the United States of America (Dugje et al., 2009). This low yield is due to several constraints: these are mainly diseases, insect pests and weeds. The losses caused by these biotic factors are estimated at nearly US\$300 million per year (NRI, 1991). However, pests and diseases are the major constraint to cowpea production (Atachi and Adeoti, 2004). Thus, the fight against pests and diseases is a major issue in the production of cultivated cowpeas. The success of the harvest depends on the success of this fight. The only suppression method available to producers is the use of synthetic chemicals. This method is effective for pest control but has disadvantages. Chemicals used for treatment can contribute to ecosystem pollution, increased risk to the health of its users and the development of resistance in insect populations (Brown, 1957).

In addition, each treatment intervention is a significant cost within a crop's production budget. This includes the purchase of plant protection products, wear and tear on machinery, fuel consumption and the producer's time to carry out this operation. Indeed, not knowing at what point in the crop's development or at what attack threshold it is important to apply a phytosanitary treatment, producers tend to apply the treatments whenever there are pests on the crop. In doing so, they perform more treatments than necessary and at times when it is often unnecessary to perform treatments. In order to reduce the costs and risks associated with phytosanitary treatments, it is necessary to reduce the number of interventions or to optimize them. One approach for efficient pest control is Critical Treatment Period (CTP) determination. It is defined as the growing period of the crop that must take place in the absence of insects in order to prevent yield losses. CTP allows applications to be targeted to optimize their effects and thus protect crop yield. This concept does not describe crop-pest interactions but focuses only on yield losses caused by the presence of pests. This approach has been used in many studies. Thus, it has been used to characterize yield losses due to weeds in different crops such as soybean (Glycine max L.) (Van Acker et al., 1993), canola (Brassica napus L.) (Martin et al., 2001) or sweet pepper (Capsicum annuum L.) (AmadorRamirez, 2002). It has also been applied with emphasis on a particular weed species such as Helianthus annuus L. (Rosales-Robles et al., 2005), on the amount of mineral resources present (Evans et al., 2003), on pest density (Norsworthy and Oliveira, 2004) or on a cropping practice such as direct seeding (Halford et al., 2001). As far as pest control of cowpea is concerned, no CTP has ever been established in Togo and CTP depends not only on the density of pests and the type of crop but also and above all on the place and growing season. To remedy this shortcoming, this study proposes as its first objective to optimize cowpea production through an economically profitable and environmentally friendly technology based on the determination of the phytosanitary CTP of a local cowpea variety (VITOCO).

\section{Materials and methods \\ The experimental site}

The present study was conducted at the Agronomic Experimentation Station of Lomé $\left(06^{\circ} 17^{\prime} \mathrm{N}\right.$, $\left.001^{\circ} 21^{\prime} \mathrm{E}\right)$, University of Lomé during the great dry season (November 2016 to January 2017). It aims to optimize cowpea production through an economically profitable and environmentally friendly technology. The test site is located in the maritime region of Togo. This region is characterized by two rainy seasons with the maximum in June and September, and an average annual rainfall of $1200 \mathrm{~mm}$ with a temperature varying between 18.5 and $32.8^{\circ} \mathrm{C}$, the minimum being in September and the maximum in October. During the trial, there was no rain and water was applied to the plants throughout the trial.

\section{Plant material}

The variety of cowpea used was chosen for VITOCO because of its wide adoption by farmers and because of its semi-erect character that can facilitate the counting of insects on the vegetative organs of plants and its short cycle (about 70 days). This variety is characterized by a semi-erect vegetative growth habit with large, trifoliate, oval, dark green leaves; the flowers are white in color and the pods are $15-20 \mathrm{~cm}$ in average length. The seeds are large, white with black hilum.

\section{Treatment equipment}

For phytosanitary treatments, the synthetic chemical used is Acarius (Abamectin) EC at a dose of 1 liter diluted in 399 liters of water per hectare. The sprayer used is a pre-pressurized hand sprayer.

\section{Setting up the culture}

The field was cleared and ploughed with a daba and the blocks and parcel units were delimited. On each 6 $\mathrm{m} \times 3 \mathrm{~m}$ plot unit, cowpea was sown with a $75 \times 20$ $\mathrm{cm}^{2}$ crop pattern with 2 seeds per poquet then started at one plant per poquet on the 10th day after sowing. This brought the sowing density to 125 plants per plot unit (5 rows of 25 plants each) or 69444 plants/ha. Three manual weeding operations were carried out.

\section{Determination of the critical period for phytosanitary treatment}

To determine CTP, we adopted an experimental design consisting of two (2) sub-tests, each being a 
complete random block design consisting of 3 blocks and with four plot units each. The two sub-tests were: the Early Competition Sub-test (EC) and the Late Competition Sub-test (LC). The plot units measured $6 \times 3 \mathrm{~m}$ or $18 \mathrm{~m}^{2}$ the blocks separated from each other by $2 \mathrm{~m}$. The two sub-tests were separated by a corn line to reduce interactions between the different treatments. The treatment consisted of applying the synthetic insecticide Acarius $018 \mathrm{EC}$ at a rate of 1 L/ha.

To study the effect of early competition, we treated by varying the treatment start dates and to study the effect of late competition, we treated by varying the treatment end dates.

Early Competition (EC):

(T1): the first object received treatments 14, 28, 42, and 56 Days After Sowing (DAS);

(T2): the second object received treatments 28, 42, and 56 DAS;

(T3): the third object received treatments 42 , and 56 DAS;

(T0): the fourth object has not received any processing.

For late competition (LC):

(T1'): the first object received treatments $14,28,42$, and 56 DAS;

(T2'): the second object has received 14,28 and 42 DAS processing;

(T3'): the third object has received treatments 14 and 28 DAS;

$(\mathrm{T} 0$ '): the fourth object has not received any treatment.

\section{Sampling methods}

The sampling method used varies depending on whether the targeted insect attacks plant parts or flowers. Thus, for Empoasca sp (Hemiptera: Cicadellidae), Aphis craccivora Koch (Homoptera: Aphididae), pests of cowpea leaves and stems, samples were taken from 6 a.m. to 9 a.m. just before the phytosanitary product was applied every day from 14 to 56 DAS, whereas for Maruca vitrata (Fabricrus) (Lepidoptera: Crambidae) and Megalurothrips sjostedti Trybom (Thysanoptera: Thripidae), pests attacking cowpea flowers, samples were taken after the appearance of flowers from 35 to 56 JAS. A. craccivora and Empoasca sp, were visually collected from 30 plants randomly selected according to the four diagonals in each plot. At each observation adults and larvae of leafhopper, Empoasca sp, and aphid A. craccivora were counted. $M$. vitrata and $M$. sjostedti were counted on 30 randomly selected plants per plot. Ten flowers were picked from each plant. The flowers collected were taken to the laboratory where the numbers of $M$. vitrata and $M$. sjostedti were counted and recorded. At harvest, a final sampling was done to evaluate certain yield parameters such as the number of pods per plant, the percentage of pods and seeds attacked by insects. The number of pods per plant was evaluated on 30 plants selected at random on the three central lines and on which no flower removal was done on the plants during the counting of $M$. vitrata and $M$. sjostedti. Damage caused by pod borers was calculated as the percentage of pods perforated by these borers and loss (in g) was calculated as the difference between the initial weight of 1000 randomly selected grains and the weight of the grains after removing the damaged grains.

\section{Yield, damage and seed loss assessment}

For yields, we assessed seed yield by treatment. Indeed, the dry pods harvested on the three central lines of each experimental unit have been shelled and the seeds are weighed using the CAMRY electronic scale.

The seed yield is calculated from the following formula:

\section{RGUP $=\sum_{i=1}^{n}$ PGRLCUP}

with RGUP = Yield in Grains per Parcel Unit; PGRLCUP $=$ Weight in Grains of the Harvest on each of the three Plant Lines of the same Parcel Unit and $\mathrm{n}=$ total number of lines per parcel unit of a given treatment.

Damage is assessed by the percentage attack and the percentage weight loss (weight loss) (Cruz et al., 1988). The damage and losses were assessed according to the method of counting and weighing (MCP). 1000 seeds from each sample of the plot unit are taken at random and sorted into lots of healthy and attacked seeds. The seed lots were weighed using an electronic scale. Damage and losses are then calculated by the following formulas (Tounou et al., 2012):

$$
\begin{aligned}
& \mathrm{D} \%=\frac{\mathrm{Na}}{\mathrm{Ns}+\mathrm{Na}} \times 100 \\
& \mathbf{P} \%=\frac{N a P s-N s \mathrm{~Pa}}{(\mathrm{~N} s+\mathrm{Na}) \mathrm{Ps}} \times 100
\end{aligned}
$$

With $\mathrm{D} \%=$ percentage of damaged seeds; $\mathrm{P} \%=$ weight loss; $\mathrm{Na}=$ number of attacked seeds; $\mathrm{Ns}=$ number of healthy seeds; $\mathrm{Pa}=$ weight of attacked seeds and Ps = weight of healthy seeds.

\section{Evaluation of the economic aspect}

Before recommending an option, you must ensure that it is economically viable. To do this, we carried out the partial balance sheet by calculating the profit for each option.

\section{Statistical analyses}

The data were analyzed after transformation by $\log$ $(\log (X+1))$ and $\operatorname{Arcsin} \sqrt{ }($ percent $\mathrm{X} / 100)$, respectively for densities and percentages and averages are 
discriminated using the Student-Newman-Keuls (SNK) test at the threshold of $\alpha=0.05$. An analysis of variance at the 5\% threshold using Genstat software was performed. After analysing the yields obtained, we drew the early and late competition curves and their superposition allowed us to determine the CTP.

\section{Results}

\section{Population structure and relative abundance of} insects on the experimental site
A total of 5222 insects were collected during the trial period (Table I). The insect pest complex observed at the experimental site during treatments is dominated mainly by $A$. cracivora inventoried on leaves and stems $(44.10 \%$ of insects collected), M. sjostedti inventoried on flowers (42.46\% of insects collected), green leafhopper, Empoasca sp (19.53\%) and $M$. vitrata larvae (Table 1). A. cracivora, M. sjostedti and Empoasca sp, represent by far the three most abundant insect species during the trial, representing about $95 \%$ of the total insect population at the time of treatment (Table I).

Table 1. Insect species present (number and percentage of total number of insects) collected at the test site during the test period.

\begin{tabular}{ll}
\hline Insect species & $\begin{array}{l}\text { Relative abundance of insects } \\
\text { inventoried on the experimental site }\end{array}$ \\
\hline A. cracivora & $2303(44.10 \%)$ \\
M. sjostedti & $1614(30.90 \%)$ \\
Empoasca sp & $1020(19.53 \%)$ \\
M. vitrata & $365(6.99 \%)$ \\
A. curvipes & $13(0.25 \%)$ \\
Mylabris spp & $7(0.13 \%)$ \\
Total & $5222(100 \%)$ \\
\hline
\end{tabular}

Insect population dynamics after application of the treatment product

The effect of application of the chemical on the evolution of pest populations inventoried on leaves and stems is presented in Table 2. At the level of early competition, no significant differences were noted for the population density level of Empoasca sp and A. cracivora between plots before the start of treatments (Table 2). On the control plot, the population level of these two insects increased significantly over time $(\mathrm{P}<0.005)$ while on the insecticide-treated plots, the population level initially decreased and then stabilized when treatment continued. For plots that received a treatment on the 14th day after permanent treatment, the Empoasca sp population stabilised after the second application, whereas for A. cracivora stabilization occurred only after three treatments (42 DAS). For plots that received treatments after $28 \mathrm{DAS}$, only one treatment stabilized the populations of the two insects. For plots that received treatments from 42 DAS, the population of both insects decreased significantly but since there was only one count after, we cannot confirm whether insect populations stabilized or not. After application, the overall population size of these insects has remained stable after one or two applications depending on the pest except in the case where treatment is initiated at 42 DAS for which stabilization cannot be confirmed (Table 2).
At the level of late competition, similarly, no statistical difference was observed between the populations levels of Empoasca sp and A. cracivora between plots before the start of treatments (Table 2). For permanent treatment, the population evolution of the two insects is identical to that described above except for Empoasca sp where the number remains stable up to 42 DAS. On the control plot, the population level of these two insects increased significantly over time $(\mathrm{P}<0.005)$ as previously, whereas on the insecticide-treated plots, the population level decreased initially and then began to increase significantly once the treatment was finished, especially for aphids, except on the plot where the treatment stopped at 42 DAS where the numbers of these two pests remained constant despite not being treated.

Results showed that the chemical used significantly reduced the development of the two cowpea insect pests $(\mathrm{P}<0.05)$. In addition, a single treatment carried out on 28 DAS reduced the numbers of Empoasca sp and A. cracivora to the same level as two treatments carried out on 14 and 28 DAS. Similarly, treatments that stop at 42 DAS have stabilized populations of both insects in the same way as treatments up to 56 DAS. At control plot level the population of the two pests increases exponentially but stabilises from 56 DAS for Empoaca sp. 
Determination of the Critical Period of Phytosanitary Treatment against Cowpea (Vigna unguiculata L. Walp) Pests in Southern Togo

Table 2. Effects of early and late competing treatments on population dynamics of Empoasca sp and A. cracivora

\begin{tabular}{|c|c|c|c|c|c|c|c|c|}
\hline \multicolumn{9}{|c|}{ Days after sowing } \\
\hline & \multicolumn{2}{|c|}{14} & \multicolumn{2}{|c|}{28} & \multicolumn{2}{|c|}{42} & \multicolumn{2}{|r|}{56} \\
\hline Treatments & Empoasca sp & A. cracivora & Empoasca $\mathrm{sp}$ & A. cracivora & $\begin{array}{c}\text { Empoasca } \\
\text { sp }\end{array}$ & A. cracivora & $\begin{array}{c}\text { Empoa } \\
\text { sca sp }\end{array}$ & A. cracivora \\
\hline \multicolumn{9}{|c|}{ Early Competition Trial } \\
\hline T14-28-42-56 & $0.9 \pm 0.1 \mathrm{aA}$ & $0.8 \pm 0.1 \mathrm{aA}$ & $1.1 \pm 0.2 \mathrm{aA}$ & $1.3 \pm 0.5 \mathrm{aB}$ & $0.0 \pm 0.0 \mathrm{aB}$ & $0.4 \pm 0.1 \mathrm{aC}$ & $\begin{array}{l}0.4 \pm \\
0.1 \mathrm{aB}\end{array}$ & $0.5 \pm 0.2 \mathrm{aC}$ \\
\hline $\mathrm{T} 28-42-56$ & $0.4 \pm 0.2 \mathrm{bA}$ & $0.6 \pm 0.2 \mathrm{bA}$ & $1.5 \pm 0.5 \mathrm{aB}$ & $1.4 \pm 0.2 \mathrm{aB}$ & $0.0 \pm 0.0 \mathrm{aA}$ & $0.6 \pm 0.2 \mathrm{bA}$ & $\begin{array}{l}0.3 \pm \\
0.1 \mathrm{aA}\end{array}$ & $0.3 \pm 0.1 \mathrm{aA}$ \\
\hline $\mathrm{T} 42-56$ & $0.7 \pm 0.5 \mathrm{cA}$ & $0.6 \pm 0.5 \mathrm{bA}$ & $1.5 \pm 0.1 \mathrm{aB}$ & $1.7 \pm 0.6 \mathrm{bB}$ & $1.7 \pm 0.6 \mathrm{bB}$ & $2.2 \pm 0.5 \mathrm{cC}$ & $\begin{array}{l}0.0 \pm \\
0.6 \mathrm{aA}\end{array}$ & $0.6 \pm 0.3 \mathrm{bA}$ \\
\hline T0 & $0,8 \pm 0.5 \mathrm{aA}$ & $0.0 \pm 0.4 \mathrm{cA}$ & $1.7 \pm 0.5 \mathrm{aB}$ & $1.7 \pm 0.5 \mathrm{bB}$ & $1.9 \pm 0.6 \mathrm{bB}$ & $2.3 \pm 0.6 \mathrm{cC}$ & $\begin{array}{l}2.3 \pm \\
0.7 \mathrm{bC}\end{array}$ & $2.8 \pm 0.6 \mathrm{cD}$ \\
\hline$P$ & 0.002 & 0.001 & 0.103 & 0.004 & 0.001 & 0.001 & 0.001 & 0.001 \\
\hline $\mathrm{Cv} \%$ & 30.8 & 14.2 & 16.5 & 5.3 & 13.6 & 9.9 & 2.0 & 8.1 \\
\hline T14-28-42-56 & $0.6 \pm 0.1 \mathrm{aA}$ & $\begin{array}{l}\text { Late Compet } \\
0.3 \pm 0.1 \mathrm{a} \mathrm{A}\end{array}$ & $\begin{array}{l}\text { tion Trial } \\
0.9 \pm 0.4 \mathrm{aA}\end{array}$ & $1.10 \pm 0.4 \mathrm{aB}$ & $0.8 \pm 0.2 \mathrm{aA}$ & $0.7 \pm 0.2 \mathrm{aC}$ & $\begin{array}{l}0.0 \pm \\
0.0 \mathrm{aB}\end{array}$ & $0.6 \pm 0.1 \mathrm{aC}$ \\
\hline T14-28-42 & $0.8 \pm 0.1 \mathrm{bA}$ & $0.3 \pm 0.1 \mathrm{aA}$ & $0.6 \pm 0.3 \mathrm{bB}$ & $1.1 \pm 0.4 \mathrm{aA}$ & $0.4 \pm 0.2 b C$ & $0.8 \pm 0.1 \mathrm{aA}$ & $\begin{array}{l}0.2 \pm \\
0.1 \mathrm{aC}\end{array}$ & $0.8 \pm 0.4 \mathrm{aA}$ \\
\hline T14-28 & $0.4 \pm 0.1 \mathrm{aA}$ & $0.6 \pm 0.1 \mathrm{bA}$ & $0.7 \pm 0.1 \mathrm{bA}$ & $1.2 \pm 0.3 \mathrm{aB}$ & $1.2 \pm 0.1 \mathrm{cB}$ & $1.4 \pm 0.3 \mathrm{bC}$ & $\begin{array}{l}1.7 \pm \\
0.3 \mathrm{bC}\end{array}$ & $1.8 \pm 0.4 \mathrm{bD}$ \\
\hline T0' & $0.7 \pm 0.5 \mathrm{cA}$ & $0.84 \pm 0.5 b \mathrm{~A}$ & $1.7 \pm 0.5 \mathrm{cB}$ & $1.8 \pm 0.5 \mathrm{bB}$ & $2.2 \pm 0.2 \mathrm{dC}$ & $2.4 \pm 0.5 \mathrm{cC}$ & $\begin{array}{l}2.2 \pm \\
0.6 \mathrm{cC}\end{array}$ & $2.8 \pm 0.6 \mathrm{cD}$ \\
\hline$P$ & 0.030 & 0.001 & 0.001 & 0.001 & 0.001 & 0.001 & 0.001 & 0.001 \\
\hline $\mathrm{Cv} \%$ & 55.2 & 18.9 & 14.0 & 3.9 & 8.7 & 5.9 & 3.2 & 5.7 \\
\hline
\end{tabular}

The means of the same column followed by the same lowercase letters and the same line followed by the same capital letters are not statistically different (Student-Newman-Keuls, $\mathrm{P}<0.05$ ). EC and LC treatments in early and late competition. The figures in front of EC and LC are the days of treatment after sowing.

Table 3 shows the population trends of $M$. sjostedti and $M$. vitrata collected from flowers during the trials. At the level of early competition, statistical analysis indicated a significant increase in the population of both pests throughout the trial period on the control plots (Table III). On the plot that received a permanent treatment (treatment from the 14th to the 56th DAS), the population of M. Sjostedti stabilized after the second application (application made just before the arrival of $M$. sjostedti on the crop) and reached a level of 0 just after the application that followed at the 20th DAS. However, the $M$. vitrata population increased despite treatments before stabilizing after application but never reaching level 0. On plots that received treatment from 28th DAS onwards, $M$. sjostedti's numbers dropped considerably until reaching density 0 at the second application (42 DAS) while the $M$. vitrata population initially increased despite the first application before stabilising at the second application without reaching level 0 despite the other applications. The start of treatment from 42 JAS also gives a similar trend to the others.

At the level of late competition, the statistical analysis indicated a similar evolution to that of early competition on control plots (Table III) and on plots that received permanent treatment. The plots whose treatment ended 28 DAS saw the population of both pests increase numerically without being statistically different from the control except for the treatment at 56 DAS for $M$. vitrata.

Results showed that the chemical used significantly reduced the development of $M$. vitrata and $M$. sjostedti $(\mathrm{P}<0.05)$. However, the effect of the product was more marked on $M$. sjostedti than on $M$. vitrata. In addition, a single treatment at 28th JAS reduced the numbers of the two insects to the same level as two treatments at 14th and 28th DAS. Similarly, the treatments that stopped at the 42nd DAS stabilized the populations of the two insects in the same way as the treatments that continued until the 56th DAS.

At control plot the pest population increases until the end of the trial. 
Determination of the Critical Period of Phytosanitary Treatment against Cowpea (Vigna unguiculata L. Walp) Pests in Southern Togo

Table 3. Effects of early and late competing treatments on population dynamics of M. sjostedti and M. vitrata

\begin{tabular}{|c|c|c|c|c|c|c|c|c|}
\hline \multicolumn{9}{|c|}{ Days after sowing } \\
\hline \multirow[b]{2}{*}{ Treatments } & \multicolumn{2}{|c|}{35} & \multicolumn{2}{|c|}{42} & \multicolumn{2}{|c|}{49} & \multicolumn{2}{|c|}{56} \\
\hline & M. sjostedti & M. vitrata & M. sjostedti & M. vitrata & M. sjostedti & M. vitrata & M. sjostedti & $M$. vitrata \\
\hline \multicolumn{9}{|c|}{ Early Competition Trial } \\
\hline T14-28-42-56 & $0.9 \pm 0.1 \mathrm{aA}$ & $0.4 \pm 0.0 \mathrm{aA}$ & $1.1 \pm 0.1 \mathrm{aA}$ & $0.9 \pm 0.1 \mathrm{aB}$ & $0.0 \pm 0.0 \mathrm{aC}$ & $0.4 \pm 0.2 \mathrm{aA}$ & $0.0 \pm 0.0 \mathrm{aC}$ & $0.4 \pm 0.2 \mathrm{aA}$ \\
\hline T28-42-56 & $1.4 \pm 0.2 \mathrm{bA}$ & $0.4 \pm 0.2 \mathrm{aA}$ & $1.2 \pm 0.1 \mathrm{aA}$ & $0.8 \pm 0.2 \mathrm{aB}$ & $0.3 \pm 0.1 \mathrm{aB}$ & $0.5 \pm 0.1 \mathrm{aA}$ & $0.0 \pm 0.0 \mathrm{aB}$ & $0.6 \pm 0.1 \mathrm{aA}$ \\
\hline T42-56 & $1.5 \pm 0.4 \mathrm{bA}$ & $0.83 \pm 0.3 \mathrm{bA}$ & $1.7 \pm 0.2 \mathrm{bB}$ & $1.3 \pm 0.2 \mathrm{bB}$ & $0.7 \pm 0.1 \mathrm{bC}$ & $0.7 \pm 0.1 \mathrm{aA}$ & $0.9 \pm 0.1 \mathrm{bC}$ & $0.8 \pm 0.1 \mathrm{bA}$ \\
\hline T0 & $2.1 \pm 0.5 \mathrm{cA}$ & $0.93 \pm 0.5 \mathrm{bA}$ & $2.2 \pm 0.5 \mathrm{cB}$ & $1.5 \pm 0.4 \mathrm{bB}$ & $2.3 \pm 0.5 \mathrm{cC}$ & $1.4 \pm 0.3 \mathrm{bB}$ & $2.3 \pm 0.4 \mathrm{cD}$ & $1.5 \pm 0.3 \mathrm{cB}$ \\
\hline$P$ & 0.001 & 0.020 & 0.001 & 0.070 & 0.001 & 0.025 & 0.001 & 0.001 \\
\hline $\mathrm{Cv} \%$ & 9.6 & 23.2 & 2.9 & 30.7 & 17.4 & 39.4 & 6.0 & 21.1 \\
\hline \multicolumn{9}{|c|}{ Late Competition Trial } \\
\hline T14-28-42-56 & $0.9 \pm 0.1 \mathrm{aA}$ & $0.4 \pm 0.1 \mathrm{aA}$ & $1.2 \pm 0.1 \mathrm{aB}$ & $0.8 \pm 0.0 \mathrm{aB}$ & $0.0 \pm 0.0 \mathrm{aC}$ & $0.5 \pm 0.1 \mathrm{aA}$ & $0.0 \pm 0.0 \mathrm{aC}$ & $0.4 \pm 0.1 \mathrm{aA}$ \\
\hline T14-28-42 & $0.5 \pm 0.1 \mathrm{aA}$ & $0.7 \pm 0.2 \mathrm{aA}$ & $0.9 \pm 0.1 \mathrm{bB}$ & $0.4 \pm 0.1 \mathrm{aB}$ & $0.0 \pm 0.0 \mathrm{aC}$ & $0.7 \pm 0.1 \mathrm{aB}$ & $0.0 \pm 0.0 \mathrm{aC}$ & $0.6 \pm 0.1 \mathrm{aB}$ \\
\hline T14-28 & $1.6 \pm 0.2 \mathrm{aA}$ & $0.4 \pm 0.2 \mathrm{aA}$ & $1.9 \pm 0.2 \mathrm{bB}$ & $1.4 \pm 0.1 \mathrm{bB}$ & $2.9 \pm 0.2 \mathrm{bC}$ & $1.9 \pm 0.2 \mathrm{bC}$ & $1.8 \pm 0.2 \mathrm{aC}$ & $1.5 \pm 0.1 \mathrm{bB}$ \\
\hline T0' & $2.2 \pm 0.2 \mathrm{aA}$ & $1.1 \pm 0.2 \mathrm{bA}$ & $2.2 \pm 0.2 \mathrm{cB}$ & $1.4 \pm 0.3 \mathrm{bB}$ & $2.2 \pm 0.3 \mathrm{bC}$ & $1.6 \pm 0.3 \mathrm{cC}$ & $2.0 \pm 0.2 \mathrm{bC}$ & $1.7 \pm 0.2 \mathrm{cD}$ \\
\hline$P$ & 0.001 & 0.009 & 0.002 & 0.005 & 0.001 & 0.007 & 0.001 & 0.001 \\
\hline $\mathrm{Cv} \%$ & 17.7 & 21.7 & 14.3 & 22.8 & 8.3 & 26.2 & 27.7 & 19.2 \\
\hline
\end{tabular}

The means of the same column followed by the same lowercase letters and the same line followed by the same capital letters are not statistically different (Student-Newman-Keuls, $\mathrm{P}<0.05$ ). EC and LC treatment in early and late competition. The figures in front of EC and LC are the days of treatment after sowing.

\section{Effect of treatments on some yield parameters of VITOCO cowpea variety}

The results showed that the number and timing of application of the crop protection product influenced the number of pods per plant, the number of perforated pods, seed mass and seed losses. Whether in early or late competition, all treatments that cover 28th to 42nd DAS give a statistically higher pod count result than other treatments. In the same way, these same treatments led to a significant reduction in attacks recorded on pods as well as seed losses and the mass of 1000 grains (Table 4).

The highest pod attack and seed loss rate was recorded at control level followed by treatments at 42nd and 56th DAS for early competition, 14th and 28th DAS for late competition (Table 4). In addition, these results revealed that the number of pods, attack rate and percentage loss are statistically identical on plots whose treatments covered 28th to 42nd DAS (P $<0.05)$.

Table 4. Effects of treatments on some yield parameters of VITOCO cowpea variety

\begin{tabular}{|c|c|c|c|c|c|}
\hline Treatments & Pods per plant & Perforated pods (\%) & Seed weight & (g) & Seed losses $(\%)$ \\
\hline \multicolumn{6}{|c|}{ Early Competition Trial } \\
\hline T14-28-42-56 & $17.01 \pm 0.02 \mathrm{a}$ & $11.76 \pm 1.01 \mathrm{a}$ & $2.32 \pm 1.01 \mathrm{a}$ & & $5.47 \pm 0.03 a$ \\
\hline T28-42-56 & $16.12 \pm 1.43 \mathrm{a}$ & $12.5 \pm 2.00 \mathrm{a}$ & $2.34 \pm 0.00 \mathrm{a}$ & & $5.55 \pm 0.24 a$ \\
\hline T42-56 & $9.06 \pm 1.30 \mathrm{~b}$ & $44.4 \pm 0.33 b$ & $1.91 \pm 0.01 b$ & & $45.43 \pm 0.09 b$ \\
\hline T0 & $3.30 \pm 0.01 \mathrm{c}$ & $100 \pm 0.12 c$ & $0.61 \pm 0.40 \mathrm{c}$ & & $78.43 \pm 0.4 c$ \\
\hline \multicolumn{6}{|c|}{ Late Competition Trial } \\
\hline T14-28-42 & $15.19 \pm 1.22 \mathrm{a}$ & $11.01 \pm 0.29 \mathrm{a}$ & $2.32 \pm 2.12 \mathrm{a}$ & & $5.14 \pm 1.14 \mathrm{a}$ \\
\hline T14-28 & $13.00 \pm 1.21 b$ & $55.40 \pm 1.11 b$ & $1.66 \pm 1.22 b$ & & $33.02 \pm 0.90 b$ \\
\hline T0’ & $3.16 \pm 2.31 \mathrm{c}$ & $100.00 \pm 1.00 \mathrm{c}$ & $0.52 \pm 1.24 \mathrm{c}$ & & $80.52 \pm 1.12 \mathrm{c}$ \\
\hline
\end{tabular}

The means of the same column within a trial followed by the same letters are not significantly different (StudentNewman-Keuls, $\mathrm{P}<0.05$ ).

$\mathrm{T}=$ Treatment; the figures in front of the letter $\mathrm{T}$ are the days of treatment after sowing 
Determination of the Critical Period of Phytosanitary Treatment against Cowpea (Vigna unguiculata L. Walp) Pests in Southern Togo

Determination of the critical treatment period

The curves in Figure 1 made it possible to determine the Critical Period of Phytosanitary Treatment of the cowpea variety VITOCO in southern Togo. These curves are based on the yields obtained. The harvests obtained on the parcel subjected to early competition (first curve) showed us that the yield evolves according to the number of treatments and the time of beginning of treatment. From this curve we could see that the highest yield $(2.61 \mathrm{t} / \mathrm{ha})$ was observed on the plot that received four treatments (14-28-42-56 DAS). This yield is not significantly different $(\mathrm{P}>$ $0.05)$ from that obtained on the plot which received only three treatments 28,42 and 56 JAS (2.12 t/ha). But this yield is statistically higher than that obtained on the plot that received the first treatment at $42 \mathrm{nd}$ JAS (1.01 t/ha) and the control $(0.21 \mathrm{t} / \mathrm{ha})$. We can then deduce that the best date to start treatment for optimum yield of cowpea, VITOCO variety is the 28th DAS.

The second curve represents the evolution of the yields obtained on the parcel subject to late competition according to the number and end time of treatment. The curve also showed that the highest yield was obtained numerically on plots that received four treatments $(2.70 \mathrm{t} / \mathrm{ha})$. However, this yield is statistically equal to that obtained on plots that received only three treatments $(2.62 \mathrm{t} / \mathrm{ha})$ on the $14 \mathrm{th}$, 28th and 42nd DAS. These yields are statistically higher than those obtained on the plots that received the last treatment at 28 DAS (0.90 t/ha) and the control plots that received no treatment $(0.23 \mathrm{t} / \mathrm{ha})$. This analysis shows that the best end date for optimum yield of the cowpea variety VITOCO corresponds to the 42 nd DAS.

The combination of the two curves (Figure 1) allowed us to determine the treatment period that allows us to have the best yield with fewer treatments. This period is between the 28th and $42 \mathrm{nd}$
DAS. Thus, any phytosanitary treatment carried out before the 28th DAS and after the 42nd JAS on cowpea, the VITOCO variety in southern Togo is useless and constitutes a loss of income.

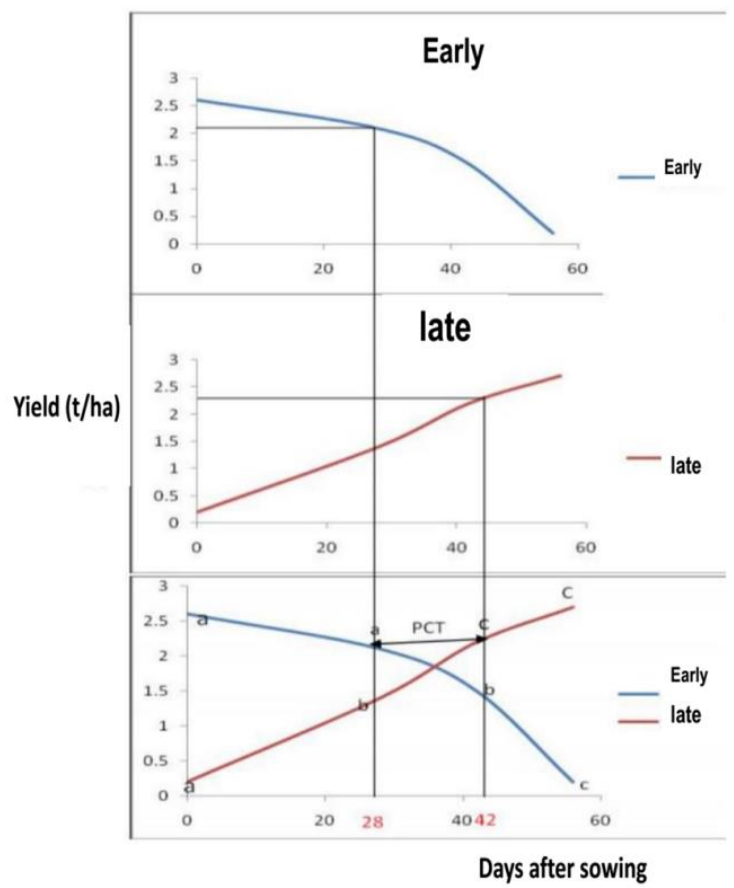

Figure 1. Determination of the critical period for phytosanitary treatment of cowpea. The identical letters on the same graph show that the difference is not significant at these dates (Student-NewmanKeuls, $\mathrm{P}<0.05)$. CTP $=$ Critical Treatments Period.

\section{Economic analysis of treatments}

Table 5 shows the income, total expenses and Gross Margin for each treatment. Thus, total expenditures include input costs (seed costs and insecticide costs) and plowing costs. The gross margin for each treatment is calculated from the formula: $\mathrm{Mb}=\mathrm{Cost}$ price - Total expenditure.

Table 5. Income, total expenditure and gross margin for each treatment

\begin{tabular}{ccccccc}
\hline Treatments & $\begin{array}{c}\text { Price / } \\
\text { bowl } \\
\text { (FCFA) }\end{array}$ & $\begin{array}{c}\text { Price / kg } \\
\text { (FCFA) }\end{array}$ & Yield (kg/ha) & $\begin{array}{c}\text { Income } \\
\text { (FCFA) }\end{array}$ & $\begin{array}{c}\text { Total } \\
\text { expenditure } \\
\text { (F/ha) }\end{array}$ & $\begin{array}{c}\text { Gross } \\
\text { margin }\end{array}$ \\
\hline T14-28-42-56 & 1200 & 480 & 2130.82 & 1022794 & 267500 & +755294 \\
T28-42-56 & 1200 & 480 & 2122.80 & 1018944 & 253500 & +765444 \\
T42-56 & 1200 & 480 & 1010.00 & 484800 & 207500 & +277300 \\
T0 & 1200 & 480 & 212.27 & 101890 & 167500 & -65610 \\
& & Late Competition & & & \\
T14-28-42-56 & 1200 & 480 & 2240.71 & 1075541 & 267500 & +808041 \\
T14-28-42 & 1200 & 480 & 2222.50 & 1066800 & 253500 & +813300 \\
T14-28 & 1200 & 480 & 900.01 & 432005 & 207500 & +224505 \\
T0 & 1200 & 480 & 231.01 & 110885 & 167500 & -56615 \\
\hline
\end{tabular}

$\mathrm{T}=$ treatment; the numbers in front of $\mathrm{T}$ are the days of treatment after sowing. 


\section{Discussion}

The aim of the sustainable pest management strategies adopted in this study is to minimise the economic loss caused by insect pests by minimising the number of applications of plant protection products. In the agro-ecological zone of the Maritime Region of Togo, insects, most of whose species attack the plant at all phenological stages, have been inventoried on cowpea. These species cause considerable damage causing considerable losses and diminishing the commercial value of cowpea seed. For example, the use of ACARIUS EC synthetic chemical insecticide at a rate of $1 \mathrm{~L} / \mathrm{ha}$ has been effective in controlling cowpea pests in field conditions. ACARIUS 018 EC being a pyrethroid (which acts by contact and ingestion) has been effective on pests due to its broad spectrum of action. These results confirm the studies carried out by Atachi and Sourokou (1989) which indicated the effectiveness of the Decis which is also a pyrethroid on M. vitrata and M. sjostedti.

In terms of early competition, the results revealed that on the treated plots, insect populations initially decreased and then stabilized when treatment continued. When the treatment is done very early (14th DAS) the population of these two pests drops considerably but 14 days after the first treatment, the population of these pests becomes very important again and even tends to approach the number obtained on the untreated plots. This may be explained by the very high multiplication capacity of these two pests. Moreover, since these pests feed on vegetative organs, the vigour of cowpea during the 28 DAS can also favour their multiplication. These results corroborate those of Carvalho et al. (2012) who showed that pest population growth increases with the vegetative state of the host plant and drops considerably when the plant loses its foliage. Slower population growth of the two pests on the control plots at the end of the cowpea vegetative phase is also evidence that these pests grow according to the vigour of the plant. However, when a second treatment is applied at 28th DAS, 14 days after the first, the population of Empoasca sp is completely eliminated, whereas a third application is still required at 42nd DAS to see the population of A. cracivora disappear completely from the plots. This would be due to the fact that A. cracivora has a higher resistance capacity than Empoasca sp. Indeed, Empoasca sp initially only interacted with crops such as rice (Djiba, 1986), Jatropha and Coffee and it is only recently that this pest is found on crops such as cowpea. Since rice, jatropha and coffee are not very often treated, these pests could not develop resistance against synthetic insecticides. However, A. cracivora, which has long been found on most legumes, especially cowpeas, and regularly receives synthetic phytosanitary products, has had time to adapt better and/or develop greater resistance to phytosanitary products (Lyon Laboratory, Plant Protection Products Resistance Unit, August 2013).

For plots that only received the first treatment at 28 DAS, a single treatment stabilised populations of both pests but at a slower rate in A. cracivora. This would be due to the fact that the first treatment took place too early (14th DAS). Indeed, at the first treatment, plants were very poorly developed, and pests were few on the plots. It was only after this that the pest population began to grow with the development of the plants. At first application, the pest threshold was not reached to allow more effective and efficient control.

In terms of late competition, the ability of both pests to multiply after application was much more dependent on the end of the date of treatment.

Our research results revealed that the best treatment start date for early competition to better control Empoasca sp and A. cracivora would be in the 28th DAS round while the best treatment end date for late competition would be in the 42 nd DAS round. The low capacity of pests to multiply when the treatment goes until the 42nd day after sowing, would be due on the one hand to the decrease of vegetative organs such as leaves at this period. The results in the control also confirm this hypothesis. On the other hand, this low multiplication is due to the fact that the treatment period covered the population pest threshold of these pests. These results are slightly different from those found by Dugje et al. (2009) which reveal that to better control A. cracivora, it is imperative to start treatments between the 30th and the 35th DAS for the variety VITOCO. This difference would be due to the fact that our work was carried out during the dry season, which would not only have shortened the development cycle of the crop but also the high temperature of the dry season would have favored the early arrival of pests.

At the 35th DAS, the devastating action of flower thrips on flower buds and especially flowers were supported by damage from pod borers, M. vitrata. Indeed, the strong pressure of these various insect pests listed on cowpea in our study area, caused stunting and browning of fruiting organs (flowers and pods) due to the feeding of the latter. This state of the plant can cause its death if nothing is done. Thus, these insects listed in the field were considered as important pests of cowpea in the present study. In general, the insecticide used (Acarius) in peasant environments considerably reduced the population of the two insect pests compared to controls. The degree of control of $M$. sjostedti and $M$. vitrata is reflected in 
damage control on fruiting bodies (flower buds, flowers, pods) of cowpea. Acarius which is a pyrethroid whose active ingredient is deltamethrin, was initially effective on the two cowpea insect pests because of its broad spectrum of action. These results confirm the studies conducted by Atachi and Sourokou (1989) which indicate the efficacy of the Decis on $M$. vitrata. However, considering the results of our trials, whether in early or late competition, we find that Acarius has better controlled the other insects listed than $M$. vitrata. This leads us to hypothesize that $M$. vitrata has developed resistance to this insecticide over the years. It is therefore important to consider other methods to control this pest, in particular biological control. Tounou et al. (2012) therefore found that aqueous plant extracts could significantly reduce the population density of cowpea pests in field conditions.

The results of our studies have shown that ladybirds have been present on crops whenever aphids are present. Since ladybirds are not devastating to cowpeas, we can deduce that aphids would be prey for ladybirds. These results corroborate those of Morin and Chouinard (2014) who demonstrated that where there are aphids, there are ladybirds. Ladybirds can therefore be used as a biological control against aphids. Indeed, an indigenous ladybird larva can consume up to 50 per day compared to 100 per day for Asian ladybird larvae (Morin and Chouinard, 2014). On untreated plots, the growth rate of aphids increases faster than that of ladybirds. This would be due to the fact that ladybirds were not sufficient to control aphids. According to Dugje et al. (2009), in the absence of heavy rains, the aphid populations can double each day. Since the rate of ladybird multiplication is much lower than that of aphids, we can deduce that in natural conditions, ladybirds alone cannot effectively control aphids. This hypothesis confirms the results of Al-Marzra'Awi et al. (2007) when he states that biological control of aphids must be done by a combination of several natural enemies, namely ladybirds (Coccinellidae) and chrysopes (Chrysopidae), Hemerobiidae, Coniopterygidae, Syrphidae, Cecidomyidae, Geocoridae, Miridae, Nabidae, Reduviidae, Chamaemyiidae.

The extent of the effect of pest damage on yield depends on the start and end date of treatment. The very high seed loss rate (79 to $80 \%$ ) in untreated plots shows the importance of plant protection for cowpea cultivation. Thus, research by Dugje et al. (2009) has shown that damage due to insect pests can reach $80-100 \%$.

At the level of treated plots, the higher pod attack and seed loss rate was recorded at the level of plots that received treatments only on the 42nd and 56th DAS for early competition, the 14th and 28th DAS for late competition. These results showed us then that a treatment that stops before the flower buds appear is not effective as well as a treatment that begins after the pods begin to mature. These results confirm those found by Dugje et al. (2009) where he demonstrated that $M$. vitrata and $M$. sjostedti alone can cause 60 to $70 \%$ yield loss in cowpeas. As these pests only attack flowers and pods it is important that the treatment period covers the flowering and fruiting phase in our case, between the 28th and 42nd DAS.

The yields obtained are consistent with infestation situations and observed damage rates on the one hand and with the timing of large fluctuations of the main pests such as A. cracivora, $M$. sjostedti and $M$. vitrata on the other. According to Atachi et al. (2007), damage, yield losses of cowpea due to aphids and thrips are between 20 and $80 \%$ when their numbers are very high at the time of flowering. Feeding these insects on cowpea flowers and pods reduces cowpea production. The percentages of damaged organs were thus considerably reduced following the application of insecticides between the 28th and 42nd DAS. Furthermore, Djiéto-Lordon et al. (2007) showed that M. sjostedti can cause up to $80 \%$ loss of cowpea flowers and therefore should not be found on the plant, especially during the fruiting period.

The calculation of gross margins showed that the gain obtained was higher on parcels T28-42-56 followed respectively by parcels T14-28-42-56, T4256 and T0 for early competition and on parcels T1428-42 followed respectively by parcels T14-28-4256, T14-28 and T0 for late competition. The two additional treatments therefore did not significantly increase yield but contributed to additional environmental pollution. Moreover, these results showed that the gain obtained is statistically identical on plots T28-42-56 of early competition and on plots T14-28-42 of late competition. Therefore, the treatments carried out at 14 DAS and 56 DAS seem unnecessary. However, each treatment intervention is a significant cost on a crop's production budget. This includes the purchase of crop protection products, machinery wear and tear, fuel consumption and the producer's time to complete this operation (Swanton and Weise, 1991).

\section{Conclusion}

The work reported in this study consisted in determining the "Critical Period of Phytosanitary Treatment for an economic and respectful production of the environment. The results of this work led to the following conclusions: The critical period for the phytosanitary treatment of cowpea, the VITOCO variety in southern Togo is between the 28th DAS and the 42nd DAS. This CPT depends not only on the 

in Southern Togo

density of pests and diseases, but also and above all on the phenological phase of the crop. In our conditions, it is situated between the beginning of flower buds and the appearance of pods. Any treatment below 28th DAS and beyond 42nd DAS seems unnecessary.

\section{Acknowledgement}

The authors thank Dr. TCHABI Atti at the "Institut des Métiers d'Agriculture (ISMA), Université de Kara" for his critical comments and review of this paper.

\section{References}

1. Al-Marzra'Awi, M.S. Kevan, P.G. et Shipp, L., 2007 Development of Beauveria bassiana dry formulation for vectoring by honey bees Apis mellifera (Hymenoptera: Apidae) to the flowers of crops for pest control. Biocontrol science and technology, vol. 17, no. 7, p. 733-741.

2. Amador-Ramirez M.D., 2002. Critical period of weed control in transplanted chillipepper. Weed Research 42:203-209.

3. Atachi P. et Sourokou B., 1989. Use of decis and systoate for the control of Maruca testularis (Geyer) in cowpea. Insect sci. Applic. 3373-381.

4. Atachi P. et Adeoti R., 2004. Interaction plante- animal : un cas d'étude d'utilisation de quelques formulations combinées d'insecticides dans la gestion des insectes ravageurs de niébé, Vigna unguiculata (L.) Walp. au Sud-Bénin - Sciences du Végétal, $2: 7-21$

5. Atachi P., Dannon E. A. et Rurema D. G., 2007. Trap cropping and intercropping of pigeonpea (Cajanus cajan Millsp) in pest management of cowpea (Vigna unguiculata) in southern Bénin: competing risk and pest status in pod attack. Annales des Sciences Agronomiques du Bénin 9 (1), $1-20$

6. Brown A.W. N., 1957. Insecticide resistance and darwinism. Botyu-Kagaku, 22, 277-282

7. Carvalho G. A., Reis P. R., Moraes J. C., Fuini L. C., Rocha L. C. D.; Goussain M. M., 2012. Efeitos de alguns inseticidas utilizados na cultura do tomateiro (Lycopersicon esculentum Mill.) a Trichogramma pretiosum Riley, 1879 (Hymenoptera: Trichogrammatidae)

8. Cruz Mendez, A. V. ; Corchado Juarbe, N. ; Siberio Torres, V., 1988. Storage and digestibility, voluntary intake and chemical components of hay of five tropical grasses. J. Agric. Univ. P. Rico, 72 (4): 531-543.

9. Djiéto-Lordon C., Aléné D. C. et Reboul J. L., 2007. Contribution à la connaissance des insectes associés aux cultures maraichères dans les environs de YaoundéCameroun Cam J. Biol. Biochem. Sc., 15, 1-13.

10. Dugje I. Y., Omoigui L. O., Ekeleme F., Kamara A. Y. \& Ajeigbe H., 2009. Production du niébé en Afrique de l'Ouest guide du paysan. IITA-Ibadan, $26 \mathrm{p}$

11. Djiba Saliou, 1986. La dynamique des populations des ravageurs ; éléments essentiels pour une protection intégrée des cultures vivrières de basse Casamance. Centre de Recherche Agricole CRA- Djibelor, 54p.

12. Evans, S.P., Knezevic S.Z., Lindquist J.L, et Shapiro C.A. 2003. Influence of nitrogen and duration of weed interference on corn growth and development. Weed Science 51:546-556.

13. FAO, 2009. Agricultural production crop primary database. Food Agricultural Organisation of the United Nations, Rome.www.Faostat.Fao./faostat.

14. FAOSTAT 2013. Site internet : http://www.faostat.fao.org

15. Halford C, Hamill A.S., Zhang J., et Doucet C. 2001. Critical period of weed control in no-till soybean (Glycine max) and corn (Zea mays). Weed Technology 15:737-744.

16. Lyon Laboratory, August 2013. Plant Protection Products Resistance, 57p.
17. Martin, S.G., Van Acker R.C. et Friesen L.F. 2001. Critical period of weed control in spring canola. Weed Science 49:326-333

18. Morin Y. et Chouinard G. 2014. Les pucerons. Dans G. Chouinard (coord): Guide de référence en production fruitière intégrée à l'intention des producteurs de pommes du Québec. Institut de recherche et de développement en agroenvironnement, Québec, QC, 56p.

19. Norsworthy J. K. et Oliveira M. 2004. Comparison of the critical period for weed control in wide- and narrow-row corn. Weed Science 52: 802-807.

20. NRI., 1991. Aperçu général de la lutte biologique intégrée dans les pays en développement, Natural Ressources Institut, Chattham, 20p.

21. Pasquet R. S., Baudoin J. P. 1997. Le niébé, Vigna unguiculata. In Charrier A., Jacquot M., Hammon S., Nicolas D. (eds). l'amélioration des plantes tropicales. Montpellier, France: cirad-orstom, 483-505.

22. Rosales-Roblès E. R., Sanchez-de de la Cruz, et SalinasGarcia J.R. 2005. Critical period of competition of wild sunflower (Helianthus annuus L.) in grain sorghum. Agrociencia 39: 205-210.

23. Rusoke D. G. \& Rubaihayo P. R. 1994. The influence of some crop protection management practices on yield stability of cowpeas. Afr. Crop Sci. J 2, 143-148.

24. Singh S. R., Jackai L.E.N., Dos Santos J. H. R. et Adalla C B. 1990. Insect Pest of Cowpea. In: Insect Pests of Tropical Food Legumes. 43-89.

25. Swanton C. J. et Weise S.F. 1991. Integrated weed management: the rational and approach. Weed Technology 5 : 657-663

26. Tounou A. K., Sokame B. M., Akpavi S., Ganyo K., Ketoh K. G., Gumedzoe Y. Mawuena D. 2012. Effets des extraits végétaux sur la dynamique de populations des insectes ravageurs de niébé, Vigna unguiculata Walp, Dans le sud du Togo. J. Rech. Sci. Série A, 14(1): 25-34.

27. Van Acker R. C., Swanton C.J., et Weise S.F. 1993. The critical period of weed control in soybean [Glycine $\max (\mathrm{L}$.) Merr.]. Weed Science 41: 194-200. 